Egle Mocciaro, William Michael Short (Eds.)

Toward a Cognitive Classical Linguistics

The Embodied Basis of Constructions in Greek and Latin 

Egle Mocciaro, William Michael Short (Eds.)

\section{Toward a Cognitive Classical Linguistics}

The Embodied Basis of Constructions in Greek and Latin

Managing Editor: Katarzyna Grzegorek

Series Editor: Cinzia Russi

Laguage Editor: Deirdre Adrienne Dunlevy

\section{DE GRUYTER}


ISBN 978-3-11-061633-0

e-ISBN 978-3-11-061634-7

\section{(cc) BY-NC-ND}

This work is licensed under the Creative Commons Attribution-NonCommercial-NoDerivs 3.0 License. For details go to http://creativecommons.org/licenses/by-nc-nd/3.0/.

(c) 2019 Egle Mocciaro, William Michael Short

Published by De Gruyter Poland Ltd, Warsaw/Berlin

Part of Walter de Gruyter GmbH, Berlin/Boston

The book is published with open access at www.degruyter.com.

\section{Library of Congress Cataloging-in-Publication Data}

A CIP catalog record for this book has been applied for at the Library of Congress.

Managing Editor: Katarzyna Grzegorek

Series Editor: Cinzia Russi

Laguage Editor: Deirdre Adrienne Dunlevy

www.degruyter.com

Cover illustration: Shauna / gettyimages.com 